\title{
REVIEW
}

\section{Clinical review: Stem cell therapies for acute lung injury/acute respiratory distress syndrome - hope or hype?}

\author{
Mairead Hayes ${ }^{1,2}$, Gerard Curley ${ }^{1,2}$, Bilal Ansari, ${ }^{1,2}$ and John G Laffey ${ }^{1,2,3 *}$
}

\begin{abstract}
A growing understanding of the complexity of the pathophysiology of acute lung injury (ALI)/acute respiratory distress syndrome (ARDS), coupled with advances in stem cell biology, has led to a renewed interest in the therapeutic potential of stem cells for this devastating disease. Mesenchymal stem cells appear closest to clinical translation, given the evidence that they may favourably modulate the immune response to reduce lung injury, while maintaining host immune-competence and also facilitating lung regeneration and repair. The demonstration that human mesenchymal stem cells exert benefit in the endotoxin-injured human lung is particularly persuasive. Endothelial progenitor cells also demonstrate promise in reducing endothelial damage, which is a key pathophysiological feature of ALI. Embryonic and induced pluripotent stem cells are at an earlier stage in the translational process, but offer the hope of directly replacing injured lung tissue. The lung itself also contains endogenous stem cells, which may ultimately offer the greatest hope for lung diseases, given their physiologic role in replacing and regenerating native lung tissues. However, significant deficits remain in our knowledge regarding the mechanisms of action of stem cells, their efficacy in relevant pre-clinical models, and their safety, particularly in critically ill patients. These gaps need to be addressed before the enormous therapeutic potential of stem cells for ALI/ARDS can be realised.
\end{abstract}

*Correspondence: john.laffey@nuigalway.ie

2Department of Anaesthesia, Clinical Sciences Institute, National University of Ireland, Galway, Galway, Ireland

Full list of author information is available at the end of the article

\section{Acute lung injury/acute respiratory distress syndrome - a therapeutic challenge}

Acute lung injury (ALI) and acute respiratory distress syndrome (ARDS) are the leading cause of death in critical care, with mortality rates of 40 to $60 \%$. In the US alone, there are 200,000 new cases annually [1]. ALI/ ARDS also constitute a considerable long-term illness and disability burden, with significant neuromuscular, pulmonary and psychological morbidity seen in 50 to $70 \%$ of survivors, and just $49 \%$ returning to employment one year post-discharge [2]. Despite being a focus of ongoing intensive research efforts over four decades, there are no pharmacologic therapies for ALI/ARDS [3]. Largescale clinical trials of multiple therapeutic strategies, including nitric oxide [4,5], anti-oxidants [6-9], surfactants [10], corticosteroids [11] and immunomodulating agents such as IL-10 [12] and granulocyte-macrophage colony-stimulating factor [13] have all failed. Consequently, advances in the management of ALI/ARDS have relied on improvements in supportive measures, such as 'protective' mechanical ventilation strategies [3], restrictive intravenous fluid management approaches [14], and prone positioning of severely hypoxaemic patients $[15,16]$. While these and other improvements in supportive care have decreased mortality [17], the failure of pharmacologic therapies suggests the need to consider novel approaches for ALI/ARDS.

ALI/ARDS is a highly complex disease process. Earlier concepts of distinct disease phases, from an early 'proinflammatory' to a later 'fibrotic' phase, now appear to be an over-simplification. These 'phases' largely co-exist, with evidence of pro-inflammatory responses leading to host damage, an impaired immune response to pathogens, and repair and fibrosis all present in the complex milieu that is clinical ALI/ARDS. Given this, it is perhaps not surprising that strategies targeted at one aspect of the disease process have been unsuccessful. This suggests the need to consider more complex therapeutic approaches aimed at reducing early injury while maintaining host immune competence, and facilitating (or at least not inhibiting) lung regeneration 


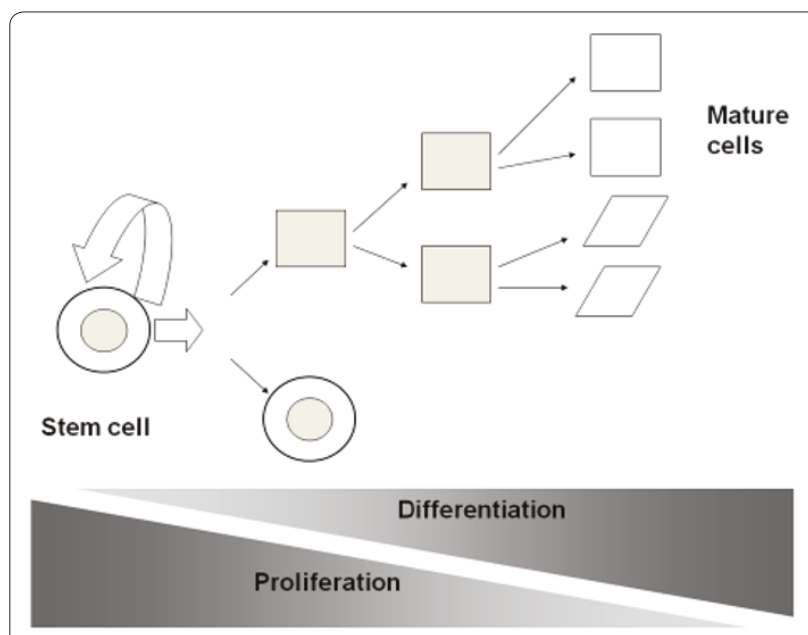

Figure 1. Schematic diagram illustrating the key properties of a stem cell. Reproduced with permission from [104]

and repair. Could stem cells fit this new therapeutic paradigm?

\section{What are stem cells?}

A stem cell is a cell that has the ability to divide asymmetrically to produce another cell like itself, or a more differentiated cell (Figure 1). Stem cells are classified based on their tissue of origin. Embryonic stem cells (ESCs) are derived from the inner blastocyst cell mass (Figure 2) and are pluripotent, that is, they are capable of differentiating into cells of all embryological lineages. Fetal stem cells are derived from extra-embryonic tissues, including the amniotic fluid, the placenta, umbilical cord blood and Wharton's jelly. They appear to represent a new stem cell population with growth kinetics and plasticity intermediate between adult and embryonic stem cells.

Adult tissue-derived stem cells include mesenchymal stem cells (MSCs), endothelial progenitor cells (EPCs), and endogenous lung stem cells (Figure 2). MSCs are cells of stromal origin that are capable of self-renewal and differentiation into cells of mesodermal origin, including chondrocytes, osteocytes and adipocytes [18]. Endothelial progenitor cells are circulating cells with the ability to proliferate and differentiate into mature endothelial cells. The adult lung itself also contains endogenous stem cells (Figure 3 ). These lung stem cells may ultimately be the ideal cell to regenerate injured lung. In general, the potential of stem cells to differentiate decreases as one moves from embryonic to adult stem cells. Adult stem cells are multi-potent, having the potential to differentiate into a more limited range of mature cell types. An exception is induced pluripotent stem cells (iPSCs), derived from adult cells that have been reprogrammed to de-differentiate following transduction with transcription factors [19].

\section{Why do stem cells offer promise for ALI/ARDS?}

Stem cells offer considerable promise as a novel therapeutic strategy for ALI/ARDS for a number of reasons. First, stem cells, particularly pluripotent cells such as ESCs or iPSCs, offer the potential to differentiate into lung cells and directly replace damaged cells and tissues. Second, ALI is characterized by an intense but transient inflammatory response. While previous strategies to simply inhibit this response have met with failure, the more complex, 'immunomodulatory' properties of adult stem cells such as MSCs may be more effective. Stem cells may be able to 'reprogramme' the immune response to reduce the destructive inflammatory elements while preserving the host response to pathogens. Third, stem cells may be able to enhance the repair and resolution of lung injury. Resolution of ALI/ARDS is impeded by destruction of the integrity of the epithelial barrier, which inhibits alveolar fluid clearance and depletes surfactant [20]. Stem cells may restore epithelial and endothelial function, whether by differentiating into these cell types or via secretion of paracrine factors to enhance restoration of these tissues. Fourth, ALI/ARDS is frequently a component of a generalized process resulting in dysfunction and failure of multiple organs. MSCs have been demonstrated to decrease injury and/or restore function in the kidney [21,22], liver [23,24] and heart [25]. Fifth, stem cells may directly attenuate bacterial sepsis, the commonest [26] and most severe [27] cause of ALI/ARDS, via a number of mechanisms, including enhancement of phagocytosis, increased bacterial clearance [28], and anti-microbial peptide secretion [29]. Sixth, there is the potential to further enhance the therapeutic effect of MSCs by tranducing them to secrete disease modifying molecules. As stem cells home to sites of inflammation when administered intravenously following tissue injury [30], they may therefore provide an attractive vector for gene-based therapies [31]. Seventh, both the distal lung epithelium and the pulmonary endothelium are selectively accessible to stem cell therapies, via the intratracheal route [32] and because the entire cardiac output transits the pulmonary vasculature. Finally, stem cells are in clinical studies for a wide range of disease processes. The clinical potential of MSCs for ALI/ARDS has been considerably enhanced by a recent study demonstrating that human MSCs can reduce endotoxin-induced injury to explanted human lungs [33].

Taken together, these findings offer considerable hope for stem cells as a therapy for ALI/ARDS. However, the potential mechanisms of action, therapeutic effects and translational potential differ significantly based on the specific stem cell population. While MSCs currently may offer the best hope of a potential therapy for ALI/ARDS [33], each stem cell population is a potential therapeutic 


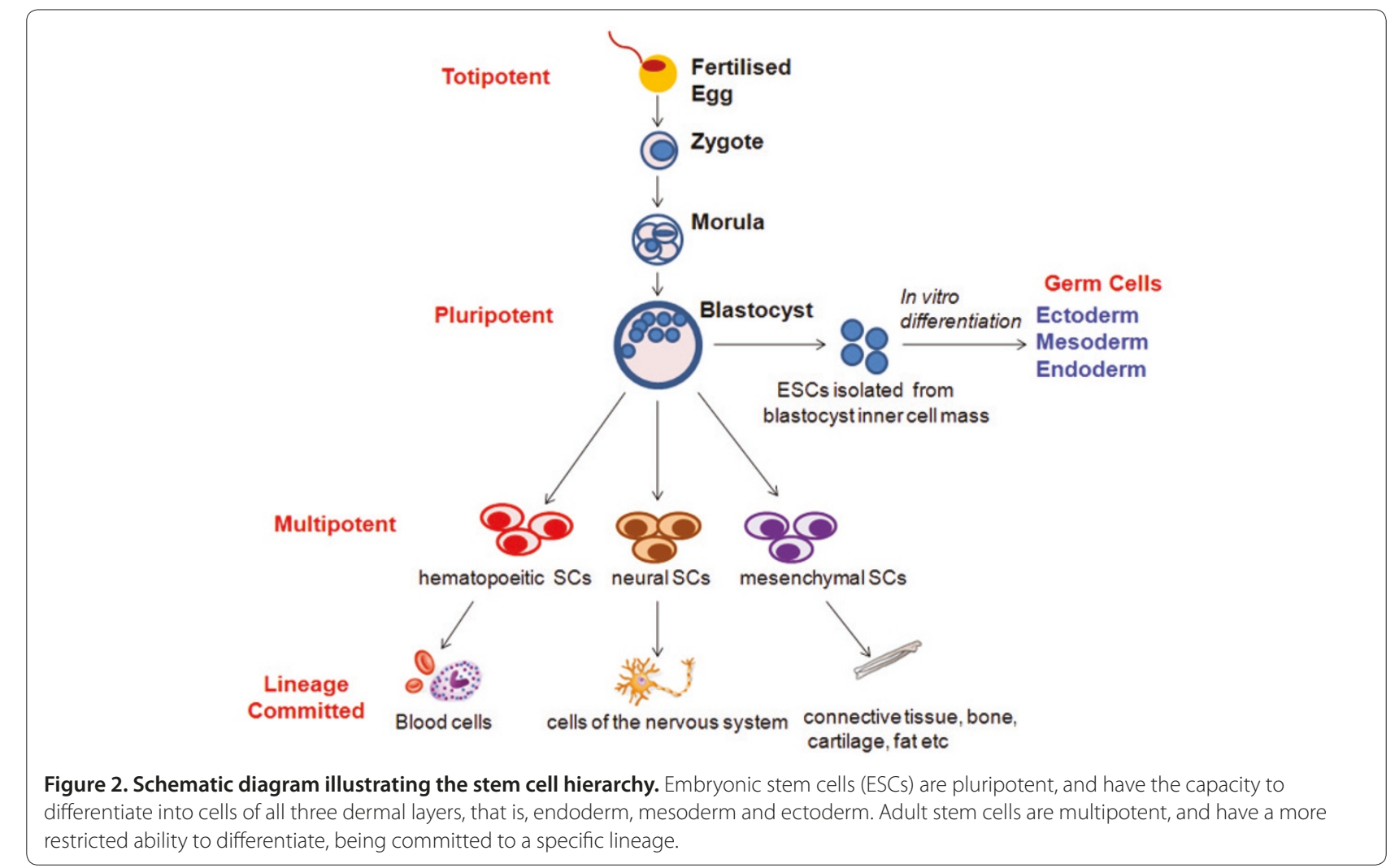

candidate (Table 1). In the following paragraphs we consider each population separately.

\section{How do stem cells work?}

Stem cells may act directly via differentiation into one or more of the injured cell types and engraftment into the organ. Indirect mechanisms of action include modulation of the injury and repair process via paracrine and cell-cell contact-dependent mechanisms. The effects of specific stem cells appear to differ depending on the stem cell type.

\section{Differentiation and engraftment}

Cellular differentiation is the process by which a less specialized cell becomes a more specialized cell type. Pluripotent ESCs or iPSCs have the capacity to differentiate into cells of all three dermal layers, that is, endoderm, mesoderm and ectoderm (Figure 2). Differentiation into the injured cell types and engraftment appears to be a key mechanism of action for these stem cell types. The derivation of alveolar epithelial cells from ESCs has been demonstrated [34].

The role of differentiation and engraftment in the mechanisms of action of adult stem cells is more controversial. Adult stem cells have a more restricted ability to differentiate, being committed to a specific lineage (Figure 2). Multipotent adult stem cells such as MSCs can differentiate into a variety of 'lineage-specific' (that is, mesenchymal) tissues, including bone, cartilage, tendon, fat, bone marrow stroma and muscle [35]. Progenitor cells, such as EPCs, have even more limited differentiation potential, being committed to a single lineage. Trans-differentiation refers to the potential for adult stem cells to differentiate into cells of other lineages [36]. Early studies suggested trans-differentiation might constitute an important mechanism of action of adult stem and progenitor cells. Krause and colleagues [37] found that a single bone marrow-derived haematopoietic stem cell could give rise to cells of multiple different organs, including the lung. Kotton and colleagues [38] demonstrated that bone marrow-derived cells could engraft into pulmonary epithelium and exhibit characteristics specific to lung epithelial cells (Figure 4). Suratt and colleagues [39] found significant rates of engraftment of transplanted haematopoietic stem cells in lung specimens from female allogeneic haematopoietic stem cell transplant recipients that received stem cells from male donors. However, more recent pre-clinical studies demonstrate that while adult stem cells can reduce ALI/ARDS, engraftment rates are low $[31,40,41]$, casting doubt on the therapeutic significance of this mechanism of action.

\section{Paracrine and cell-cell effects}

The potential for stem cells to act indirectly, by modulating key aspects of the host immune and repair 


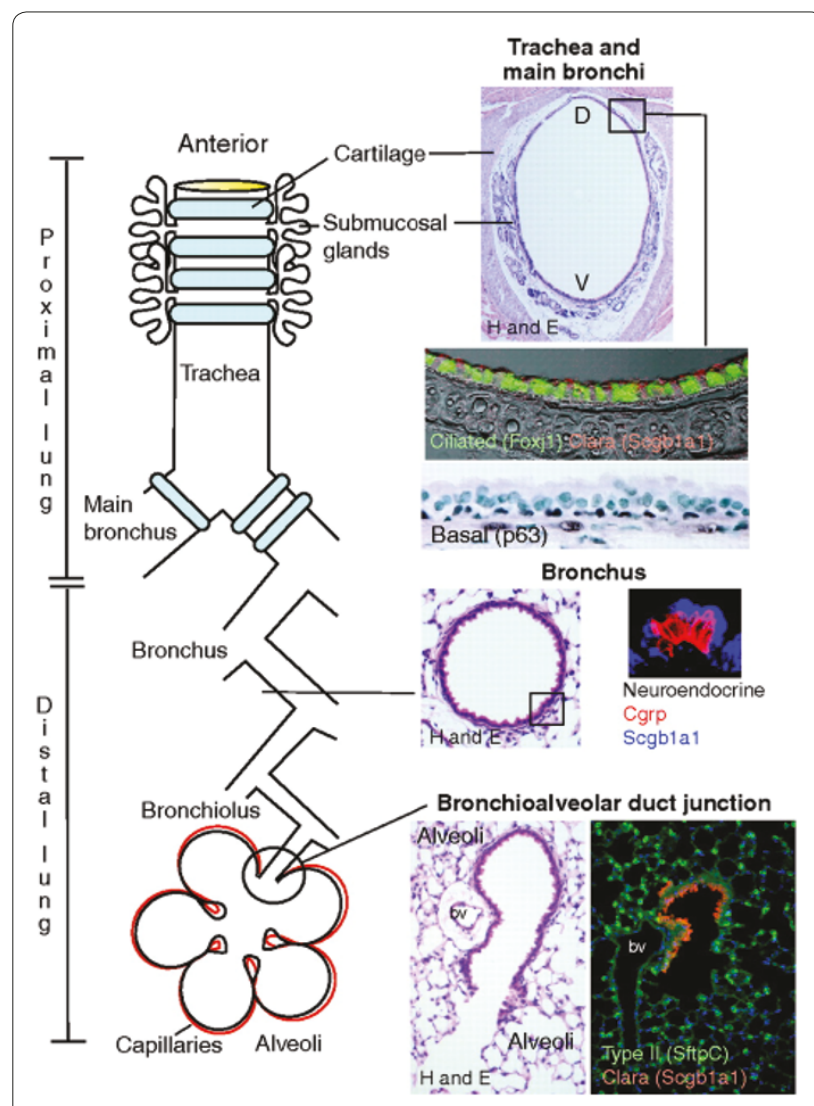

Figure 3. Schematic diagram of the microenvironmental niches that may contain lung stem/progenitor cells. In the trachea and main bronchi, undifferentiated basal cells (stained for transcription factor p63) can function as classical stem cells. Duct cells from submucosal glands located in the cartilaginous airways are also a potential niche. In the more distal lung, Clara cells and 'variant' Clara cells (stained red) are found in the bronchioles and bronchiolar-alveolar junctions, respectively, while the alveoli contain type II cells (stained green) that can regenerate type 1 pneumocytes. Reproduced with permission from [105].

responses, while potentially applicable to all stem cells types, is best understood for MSCs. MSCs secrete multiple paracrine factors, such as growth factors [42], factors regulating endothelial and epithelial permeability [43], anti-inflammatory cytokines [44], and antimicrobial peptides [29], that can modulate the immune response and facilitate repair and regeneration (Figure 5). Cell-cell contact, mediated by adhesion molecules, appears to be a key mechanism by which MSCs modulate immune effector cells such as macrophages [44] and T cells [45]. MSCs also appear to communicate with host cells by releasing membrane-derived microvesicles containing RNA [45], and mitochondria [46].

\section{Therapeutic potential of stem cells for ALI/ARDS}

A growing body of evidence highlights the potential benefits of cell-based therapy for ALI/ARDS. Most pre-clinical studies to date have focused on MSCs, and the therapeutic potential of these cells is examined in detail elsewhere [47]. However, emerging studies using ESCs, EPCs and foetal stem cells attest to the growing interest in a variety of cell-based approaches for ALI/ ARDS.

\section{Mesenchymal stem cells}

MSCs were first identified in the bone marrow in 1976 by Friendenstein and colleagues [48], but have now been identified in numerous tissues, including lung, umbilical cord, cord blood, adipose tissue and gastrointestinal tract. MSCs exhibit several advantages of relevance to ALI/ARDS, including their derivation from (multiple) adult tissues, their low immunogenicity, which means that they may be given allogeneically [49], and their relative ease of isolation and enormous expansion potential in culture.

\section{Efficacy in pre-clinical models}

MSCs have been demonstrated to reduce the severity of lung injury caused by septic and non-septic insults. Ortiz and colleagues [50] reported that MSC therapy decreased bleomycin-induced lung injury in mice despite an engraftment rate of less than 5\%. MSCs and/or their secreted factors reduced hyperoxia-induced lung inflammation, decreased histologic injury, and attenuated longterm remodelling [51,52]. Most recently, they have been demonstrated to enhance recovery and repair [53] in a model of repair following ventilation-induced lung injury [54]. Importantly, MSCs appear to enhance the host response to bacterial sepsis; they decrease septic lung injury induced by endotoxin $[40,46]$, Escherichia coli pneumonia [28] and systemic sepsis [46]. Intravenous MSC administration decreased intraperitoneal endotoxininduced alveolar neutrophil infiltration and decreased pulmonary edema [55]. MSC therapy decreased the number of bacteria recovered from the lung following E. coli instillation [56] and following cecal ligation and puncture [56]. MSCs improved survival, reduced organ dysfunction, including indices of ALI, reduced neutrophil oxidative injury and increased circulating neutrophils, while lowering bacterial counts in blood, following cecal ligation and puncture-induced systemic sepsis [44]. The anti-bacterial effects of MSCs appear to be due, in part, to the secretion of anti-microbial peptides [29].

Critical illness is characterised by dysfunction and failure of multiple organs. Reassuringly, MSCs have demonstrated efficacy in pre-clinical studies for a variety of clinical disorders, including myocardial infarction [33,57], diabetes [58], hepatic failure [59], acute renal failure [60], and sepsis $[28,44]$. The clinical potential of MSCs for ALI/ARDS has been considerably enhanced by a recent study demonstrating that human MSCs can 
Table 1. Postulated mechanisms of action of stem cells in pre-clinical models of ALI/ARDS

\begin{tabular}{|c|c|c|c|}
\hline Source & $\begin{array}{l}\text { Lung injury } \\
\text { model }\end{array}$ & $\begin{array}{l}\text { MSC delivery } \\
\text { route }\end{array}$ & Postulated mechanism of action \\
\hline \multicolumn{4}{|l|}{ Mesenchymal stem cells } \\
\hline \multirow[t]{2}{*}{ Ortiz et al. 2007 [41] } & \multirow[t]{2}{*}{ Murine bleomycin } & \multirow[t]{2}{*}{ IV } & Secretion of IL-1 receptor antagonist \\
\hline & & & Inhibition of TNF-a production by macrophage and IL-1 a-dependent T-cell line \\
\hline \multirow[t]{3}{*}{ Xu et al. 2007 [55] } & \multirow[t]{3}{*}{ Murine IP LPS } & \multirow[t]{3}{*}{ IV 1 hour post-injury } & $\begin{array}{l}\text { Production of soluble factors by MSCs that promote an anti-inflammatory } \\
\text { cytokine milieu }\end{array}$ \\
\hline & & & Paracrine effect was enhanced by cell to cell contact \\
\hline & & & Production of chemoattractants for MSCs by lung cells \\
\hline \multirow[t]{2}{*}{ Gupta et al. 2007 [40] } & \multirow[t]{2}{*}{ Murine IT LPS } & \multirow[t]{2}{*}{ IT 4 hours post-LPS } & Paracrine effect by MSCs in downregulating the inflammatory response \\
\hline & & & Engraftment rate $<5 \%$ \\
\hline Lee et al. 2009 [33] & $\begin{array}{l}\text { Exvivo perfused } \\
\text { human lung }\end{array}$ & IT 1 hour post-LPS & $\begin{array}{l}\text { Secretion of KGF by MSCs resulting in improved endothelial permeability and } \\
\text { restoration of alveolar epithelium fluid transport }\end{array}$ \\
\hline Németh et al. 2009 [44] & Murine CLP & $\begin{array}{l}\text { IV } 24 \text { hours } \\
\text { pre-injury }\end{array}$ & $\begin{array}{l}\text { Prostaglandin E2-dependent reprogramming of macrophage to increase } \\
\text { production of IL-10 }\end{array}$ \\
\hline \multirow[t]{2}{*}{ Mei et al. 2010 [28] } & \multirow[t]{2}{*}{ Murine CLP } & \multirow[t]{2}{*}{ IV 6 hours post-injury } & Modification of inflammatory gene transcriptional activity \\
\hline & & & $\begin{array}{l}\text { Down-regulation of the acute inflammatory response and up-regulation of } \\
\text { pathways relevant to phagocytosis and bacterial clearance }\end{array}$ \\
\hline $\begin{array}{l}\text { Krasnodembskaya et al. } 2010 \\
\text { [29] }\end{array}$ & E. coli pneumonia & IT 4 hours post-injury & $\begin{array}{l}\text { Secretion of the anti-microbial peptide LL-37, resulting in increased bacterial } \\
\text { clearance }\end{array}$ \\
\hline \multirow[t]{3}{*}{ Danchuk et al. 2011 [46] } & \multirow[t]{3}{*}{ Murine LPS } & IV, OA and IP & \multirow{3}{*}{$\begin{array}{l}\text { Secretion of TSG- } 6 \text { by MSCs resulting in reduced neutrophil recruitment and } \\
\text { activation } \\
\text { Secretion of KGF }\end{array}$} \\
\hline & & \multirow{2}{*}{ human MSCS } & \\
\hline & & & \\
\hline \multicolumn{4}{|l|}{ Endothelial progenitor cells } \\
\hline \multirow[t]{3}{*}{ Lam et al. 2008 [76] } & \multirow[t]{3}{*}{ Rabbit oleic acid } & \multirow{3}{*}{$\begin{array}{l}\text { IV } 30 \text { minutes } \\
\text { post-injury }\end{array}$} & Reduced expression of iNOS \\
\hline & & & Reduced lung leukocyte count \\
\hline & & & $\begin{array}{l}\text { Decreased pulmonary oedema, lung haemorrhage and hyaline membrane } \\
\text { formation }\end{array}$ \\
\hline \multirow[t]{3}{*}{ Mao et al. 2010 [56] } & \multirow[t]{3}{*}{ Rat LPS } & \multirow{3}{*}{$\begin{array}{l}\text { IV } 30 \text { minutes } \\
\text { post-injury }\end{array}$} & Anti-inflammatory-increased IL-10 \\
\hline & & & Decreased pulmonary oedema, lung haemorrhage \\
\hline & & & Reduced iNOS and ET-1 expression \\
\hline \multicolumn{4}{|l|}{ Embryonic stem cells } \\
\hline \multirow[t]{3}{*}{ Wang et al. 2010 [88] } & \multirow[t]{3}{*}{ Murine bleomycin } & \multirow{3}{*}{$\begin{array}{l}\text { IT } 1 \text { or } 2 \text { days } \\
\text { post-injury }\end{array}$} & Improved oxygenation \\
\hline & & & Decreased collagen deposition \\
\hline & & & Increased survival \\
\hline \multicolumn{4}{|l|}{ Foetal stem cells } \\
\hline \multirow[t]{2}{*}{ Moodley et al. 2009 [94] } & \multirow[t]{2}{*}{ Murine bleomycin } & \multirow{2}{*}{$\begin{array}{l}\text { IV } 24 \text { hours } \\
\text { post-injury }\end{array}$} & Anti-inflammatory-reduced IL-1, IL-6, MCP-1 \\
\hline & & & Anti-fibrotic-reduced TGF- $\beta$ \\
\hline
\end{tabular}

CLP, caecal ligation and puncture; ET-1, endothelin-1; iNOS, inducible nitric oxide synthase; IP, intraperitoneal; IT, intratracheal; IV, intravenous; LPS, lipopolysaccharide; KGF, keratinocyte growth factor; MCP-1, monocyte chemotactic protein-1; MSC, mesenchymal stem cell; OA, oropharyngeal aspiration; TGF, transforming growth factor; TNF, tumour necrosis factor; TSG-6, tumour necrosis factor alpha-induced protein 6.

reduce endotoxin-induced injury to explanted human lungs [61] (Figure 6). Taken together, these findings offer considerable hope for MSCs as a therapy for ALI/ARDS

\section{Insights from clinical studies}

MSCs are in clinical trials for multiple other diseases. In fact, the Clinicaltrials.gov database has over 100 clinical trials on its registry investigating MSCs as a therapy for diverse diseases, including diabetes, myocardial infarction, Crohn's disease, graft versus host disease, osteogenesis imperfecta and multiple sclerosis. A pilot study with 11 patients showed that MSCs were effective for radiation-induced lung injuries that developed after combined chemotherapy and radiation therapy for lymphogranulomatosis or breast cancer [62]. In a phase I study of MSCs (Prochymal ${ }^{\circ}$, Osiris Therapeutics Inc., Columbia, MD, US) in patients with acute myocardial infarction, MSCs improved forced expiratory volume in $1 \mathrm{~s}\left(\mathrm{FEV}_{1}\right)$ and forced vital capacity (FVC) [63]. These observations stimulated a multicenter phase II trial of MSCs for patients with moderate to severe chronic obstructive pulmonary disease (NCT00683722). Recent 


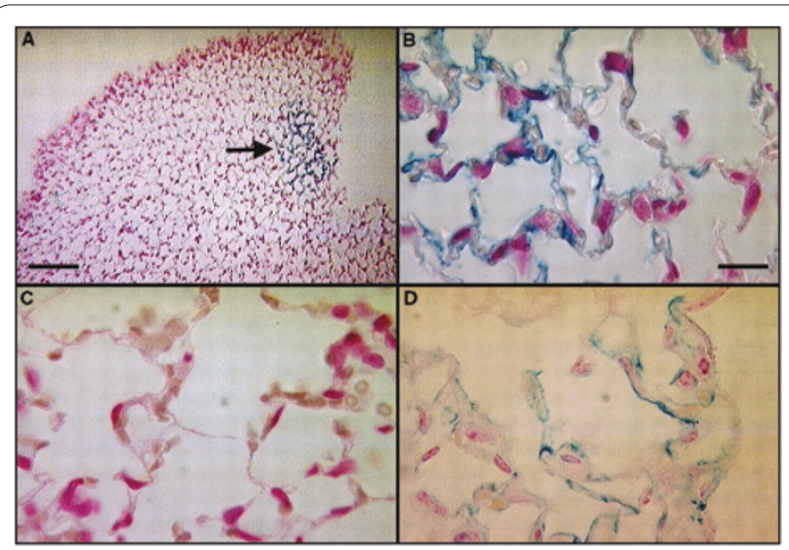

Figure 4. Transdifferentiation of mesenchymal stem cells. Photomicrographs of murine lung demonstrating engraftment of mesenchymal stem cells, which are stained blue due to their expression of the Lac- $Z$ transgene, into the mouse lung following bleomycin-induced lung injury. Reproduced with permission from [38].

clinical studies highlight the potential for MSCs to enhance wound repair. Treatment of cutaneous wounds with MSCs accelerates wound healing kinetics and increases epithelialization and angiogenesis [64-66]. These clinical trials attest to the safety of MSCs and their ability to attenuate injury severity whilst enhancing repair.

\section{Mechanisms of action}

The mechanism of action of MSCs appears to be predominantly paracrine, and to involve the release of factors that have immunomodulatory, reparative and anti-bacterial effects. In contrast to classic 'antiinflammatory' strategies, MSCs decrease host damage arising from the inflammatory response while enhancing host resistance to sepsis. MSCs interact with a wide range of immune cells and exert diverse effects on the innate and adaptive immune responses. These include suppression of T-cell proliferation, natural killer cell function and inhibition of dendritic cell differentiation [67]. Soluble factors that are candidate mediators for MSC immune modulation include transforming growth factor- $\beta$ [68], indoleamine 2,3-dioxygenase [69], IL-1-receptor antagonist [41], tumour necrosis factor- $\alpha$-induced protein (TSG)-6 [46], and IL-10 and prostaglandin E2 [44] (Figure 5). MSCs appear to augment the host immune response to sepsis via secretion of anti-microbial peptides and TSG-6, and they increased bacterial clearance and enhanced host cell phagocytosis in septic mice [28]. Recently, Krasnodembskaya and colleagues [29] reported that MSCs improved bacterial clearance of E. coli pneumonia via the secretion of an antimicrobial peptide, LL-37.
MSCs appear to aid lung repair and regeneration following injury, in part via the secretion of cytoprotective agents $[31,33,43,46]$. MSC secretion of angiopoietin and keratinocyte growth factor restores alveolar epithelial and endothelial permeability and enhances resolution of ALI/ARDS in pre-clinical models $[31,33,43,46]$. MSCs decreased bleomycin-induced lung injury and fibrosis, and decreased lung collagen accumulation, fibrosis and levels of matrix metalloproteinases in part by IL-1receptor antagonist secretion [41].

\section{Barriers to clinical translation}

The optimal route of administration of MSCs is not known, with evidence supporting the intravenous [44], intratracheal $[33,40]$ and intraperitoneal administration routes [46]. The optimal dosage regimen for MSCs, including the lower effective MSC doses, is also unclear. The true 'therapeutic' potential of MSCs - that is, their effectiveness when administered after the lung injury is established - is also unclear. Pre-clinical studies to date have used relatively poorly defined, heterogeneous MSCs. The potential for recently identified more specific MSC subpopulations [58,70] to be more effective in attenuating ALI/ARDS remains to be determined. Unlike haematopoietic stem cells, MSCs are not defined by a single marker and stem cell markers are not uniquely expressed by stem cells $[18,70]$. While a set of minimal criteria for defining MSCs has been developed [71], there remains a lack of standardised protocols for isolation and characterisation of them. Furthermore, there is no validated method of measuring MSC bioactivity in vivo [72]. Despite recent advances, our understanding of the mechanisms of action of MSCs remains incomplete. Of concern in this regard, recent studies suggest that MSCs might elicit a memory $\mathrm{T}$-cell response in mice, suggesting that they are not as 'immunoprivileged' as previously thought $[73,74]$. The need to address these barriers to clinical translation is underlined by the limited clinical experience with MSCs in critically ill patients to date [63].

\section{Endothelial progenitor cells}

Interest in EPCs stems from the fact that endothelial damage is a key pathophysiological feature of ALI, contributing to hyaline membrane formation and development of protein-rich alveolar edema [20]. While there is also no defined set of cell markers to identify an EPC, two different subpopulations of EPCs, with different differentiation abilities, cell markers and roles in endothelial repair, have been identified. 'Early' EPCs have haematopoietic surface markers (for example, CD-34) and secrete pro-angiogenic factors but display limited differentiation ability. 'Late' EPCs, so called because they appear after more than two weeks in culture, lack 


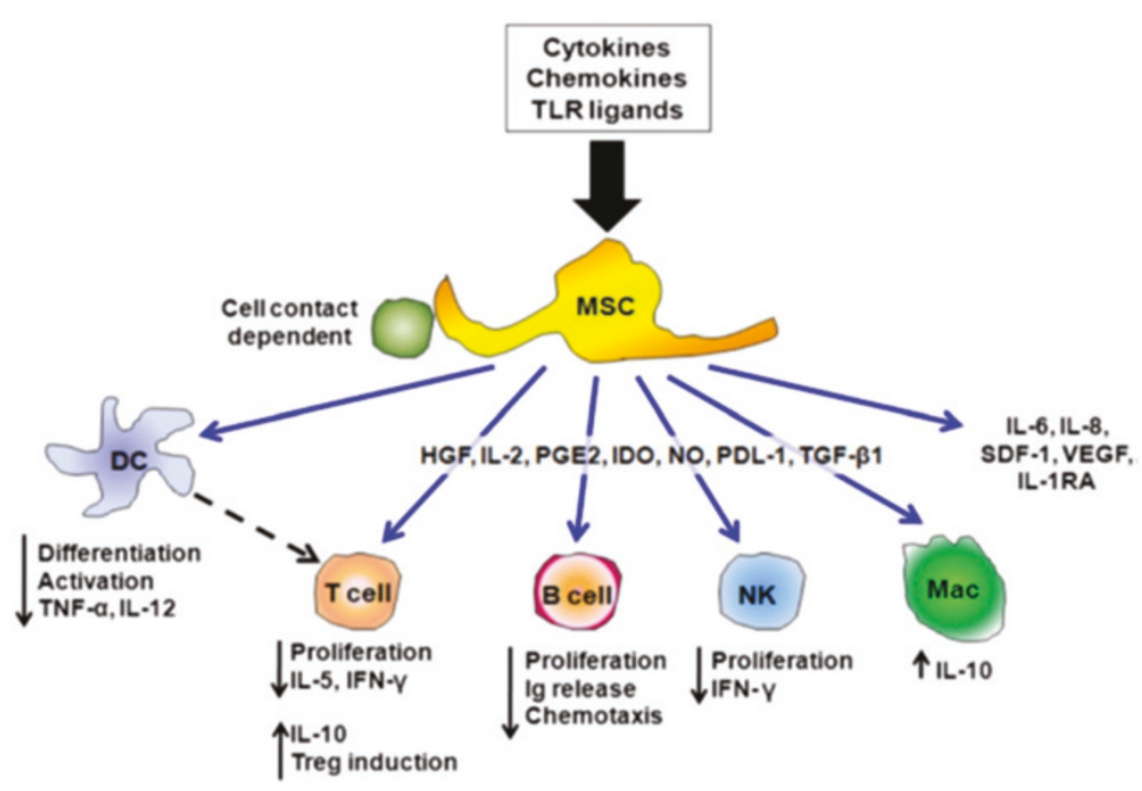

Figure 5. Schematic diagram demonstrating the potential mechanisms by which mesenchymal stem cells can modulate the immune response. DC, dendritic cell; HGF, hepatocyte growth factor; IDO, indoleamine 2,3-dioxygenase; IFN, interferon; Ig, immunoglobulin; IL-1RA, IL-1-receptor antagonist; Mac, macrophage; MSC, mesenchymal stem cell; NK, natural killer; NO, nitric oxide; PDL, Programmed death ligand 1; PGE2, prostaglandin E2; SDF, stem-cell-derived factor 1; TGF, transforming growth factor; TLR, Toll-like receptor; TNF, tumour necrosis factor; Treg, regulatory $T$ cell; $V E G F$, vascular endothelial growth factor. Reproduced with permission from [19].

haematopoietic surface markers and do not secrete proangiogenic factors. However, they make endothelioid tubes in vitro and have a greater role in replacement of damaged endothelium [75].

\section{Efficacy in pre-clinical models}

EPCs appear to regenerate the alveolar endothelium in ALI. Lam and colleagues [76] demonstrated that autologous infusion of 'early' EPCs improved alveolar-capillary integrity as evidenced by decreased lung haemorrhage, water content and hyaline membrane formation in a rabbit oleic acid ARDS/ALI model. EPCs may also exert anti-inflammatory as well as regenerative effects [56]. Animals treated with allogeneic EPCs showed increased levels of the anti-inflammatory cytokine IL-10 as well as reduced inducible nitric oxide synthase and endothelin-1 [56]. The EPC group also showed evidence of neovascularisation, re-endothelialization and improved survival. Importantly, this study was carried out using allogenic EPCs and attests to their low immunogenicity [56].

\section{Insights from clinical studies}

Human studies showing an association between increased circulating levels of EPCs and improved outcome from ALI [77] and bacterial pneumonia [78] suggest a role for EPCs in lung repair. Two clinical trials investigating the use of autologous EPCs in pulmonary hypertension have been conducted. A pilot study in children [79] and a small randomised control trial in adults [80] showed promising results with improvements in exercise capacity and pulmonary haemodynamics in the treatment group. No immunologic reactions or other adverse effects were noted from EPC infusion. A comparable trial of administration of autologous EPCs transduced to express endothelial nitric oxide synthase for adult patients with pulmonary hypertension is currently underway in Canada.

\section{Mechanisms of action}

EPCs appear to exert therapeutic effects via diverse direct differentiation and engraftment into the vasculature and via secretion of factors that mobilise adjacent endothelial cells and tissue-resident progenitor cells to partake in angiogenesis and reconstruction. The EPC secretome has recently been analyzed and found to contain at least 35 proteins known to relate to endothelial cell biology and angiogenesis [81]. As discussed above, EPCs also appear to exert immunomodulatory effects.

\section{Barriers to clinical translation}

Low circulating levels of EPCs, even in illness, mean that these cells are difficult to isolate [82]. Most studies use autologously harvested EPCs. Experience with allogeneic transplantation of EPCs is limited [56] and the safety of this approach is unconfirmed. This is a significant practical limitation that reduces their therapeutic potential for acute illnesses such as ALI/ARDS. 

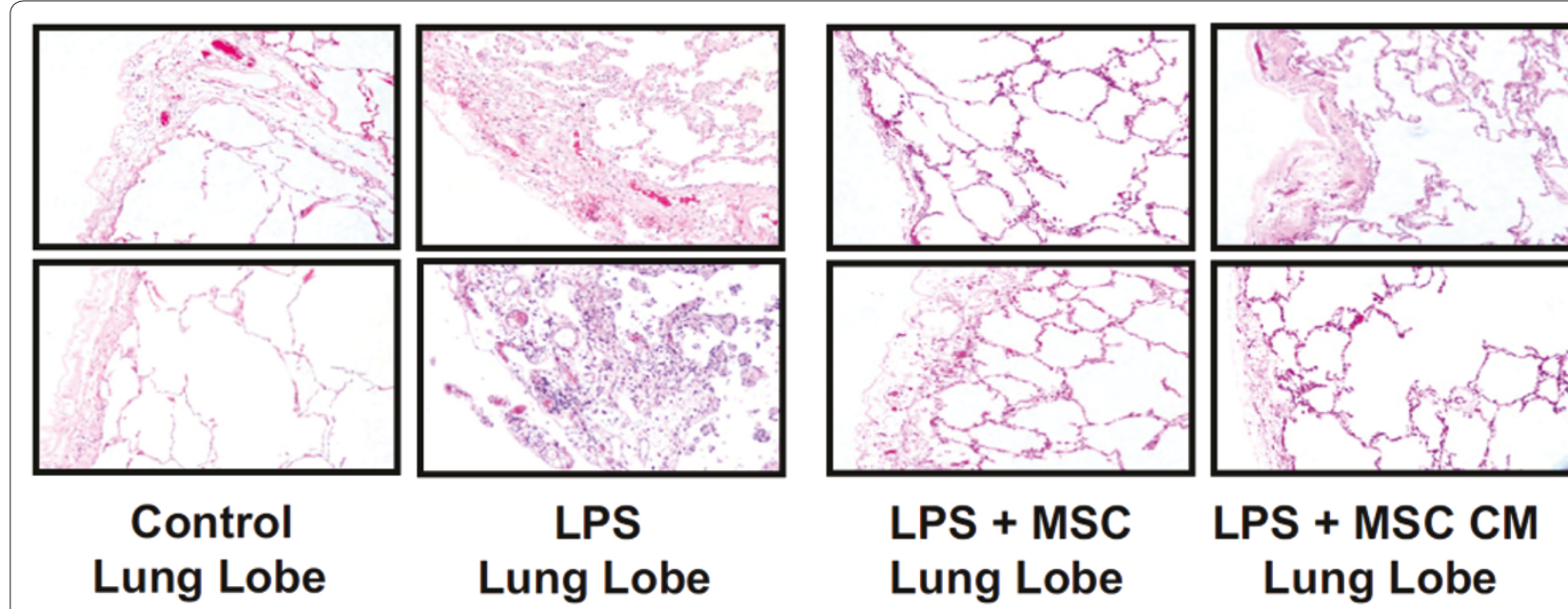

Figure 6. Human mesenchymal stem cells reduce endotoxin-induced injury in the human lung. Photomicrographs of normal lung (left), untreated endotoxin-induced lung injury, and lung treated with mesenchymal stem cells (MSCs) or with conditioned medium (CM) from MSCs. The instillation of MSCs or its CM one hour after endotoxin injury reduced lung injury, as evidenced by reduced oedema and cellularity in the endotoxin-injured lung lobe. LPS, lipopolysaccharide. Adapted with permission from [33].

\section{Embryonic stem cells}

ESCs are pluripotent cells derived from the inner blastocyst cell mass (Figure 2) and constitute a potentially unlimited source of cells that could be differentiated into lung progenitor cells for possible clinical use. The generation and implantation of a committed lung progenitor cell would have a clear therapeutic advantage, as it could give rise to all cell types within the lung following therapeutic transplantation. However, the embryologic origin of lung cells makes the generation of lung cells from ESCs difficult, and there are significant ethical issues regarding the use of these cells.

\section{Insights from laboratory studies}

Advances in ESC culture and differentiation methods in recent years have led to renewed interest in ESCs as a potential therapeutic agent in ALI [83,84]. Efforts have largely concentrated on derivation of type II alveolar epithelial cells from ESCs $[34,85]$. A difficulty is the origin of the lung in the endoderm, the third germ layer to form and one with a complex cellular specification process. Consequently, alveolar epithelial cells have proven difficult to derive from both murine and human ESCs. Wang and colleagues [34] recently derived a transfection and culture procedure utilising surfactant protein $\mathrm{C}$ promoter-driven neomycin expression to facilitate the differentiation of human ESCs into a more than 99\% pure population of type II alveolar epithelial cells. Previous techniques, including co-culture [86] with pulmonary mesenchyme, yield mixed populations of cell derivatives and were unsuitable for clinical use. Purity of cell populations for transplantation is essential as the presence of pluripotent cells in the differentiating culture engenders a significant risk of teratoma formation post-transplantation.

\section{Efficacy in pre-clinical models}

In vivo studies of ESCs as a potential replacement therapy for damaged alveolar epithelial cells in ALI remain limited $[87,88]$. The functional significance of ESC differentiation and engraftment into the injured lung remains to be clearly demonstrated [88]. Roszell and colleagues [85] developed alveolar type II (ATII) cells from mouse ESCs and administered them intratracheally into preterm mice. Over the 24-hour study period the cells maintained differentiation and surfactant protein $C$ expression. However, it was not determined if the cells had engrafted into the lung parenchyma or resulted in any functional benefit. Wang and colleagues investigated the effect of ESC-derived ATII cells on ALI in mice injured by intratracheal bleomycin [88]. At day 9 post-intratracheal administration, these human ESC-ATII cells had engrafted in the lung, and a small number had undergone differentiation to type I alveolar epithelial cells. Furthermore, the severity of ALI was reduced and animal survival increased. Most recently, Toya and colleagues [89] studied the effects of blast progenitor cells derived from human ESCs cultured in conditions favouring development of mesoderm in a mouse caecal ligation and puncture model. These cells ameliorated sepsis-induced lung injury when administered intravenously one hour post-injury by modulation of the immune response. The protective effects were mediated by a subpopulation of progenitor cells positive for the endothelial and haematopoietic lineage marker angiotensin converting enzyme. These cells interacted with CD11b+ host immune cells in 


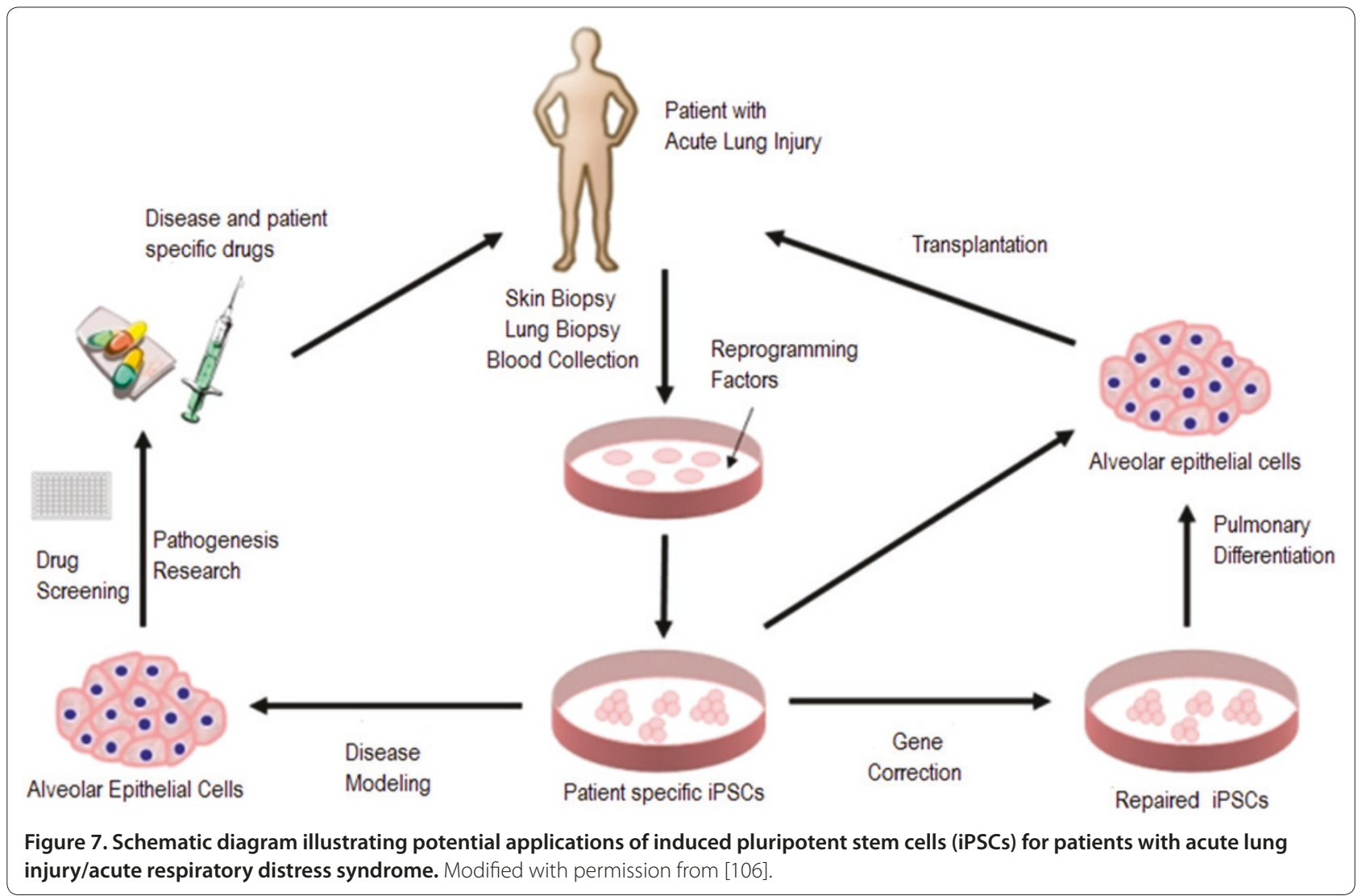

the lungs, reducing their production of pro-inflammatory cytokines and nitric oxide.

\section{Barriers to clinical translation}

Research in this field has been impeded by ethical, financial and technical concerns. Additional concerns include the potential for malignant transformation (that is, teratoma formation) [90] and immune rejection [91].

\section{Foetal stem cells}

Foetal stem cells appear to be a novel stem cell population and are derived from extra-embryonic tissues (amniotic fluid, the placenta, umbilical cord blood and Wharton's jelly). They exhibit growth kinetics and plasticity intermediate between adult MSCs and ESCs. Unlike ESCs, they demonstrate low immunogenicity in vivo [92] and do not give rise to tumours. Furthermore, given their role in foetal tolerance, these cells have immunoregulatory properties [92] that are already used clinically in ophthalmology [93] and as a therapy for burns [92]. Their derivation from extraembryonic tissues, which are normally discarded at birth, obviates the necessity for invasive biopsy or destruction of the blastocyst, and renders them an ethically neutral source of stem cells. Stem cells with a phenotype consistent with MSCs derived from
Wharton's jelly of the human umbilical cord reduce bleomycin-induced lung injury and fibrosis [94].

\section{Barriers to clinical translation}

These cells are relatively newly defined and poorly characterized. Significant additional pre-clinical study is required prior to consideration of their potential in ALI/ ARDS.

\section{Induced pluripotent stem cells}

iPSCs are adult somatic cells (for example, dermal fibroblasts) that have undergone dedifferentiation following reprogramming following transduction (using retroviruses or non-viral techniques) to express four transcription factors, Ocet3/4, Sox2, Klf-4 and c-Myc [19]. The autologous nature of the cells eliminates the problem of immune rejection associated with ESCs. iPSCs are comparable to ESCs in terms of morphology, gene expression and teratoma formation. The potential applications of iPSCs in ALI/ARDS are numerous (Figure 7).

\section{Barriers to clinical translation}

Currently there are no clinical or pre-clinical studies of the use of iPSCs for any respiratory pathology. The developmental potential of human iPSC lines has yet to be characterised. The recent demonstration of in vitro 

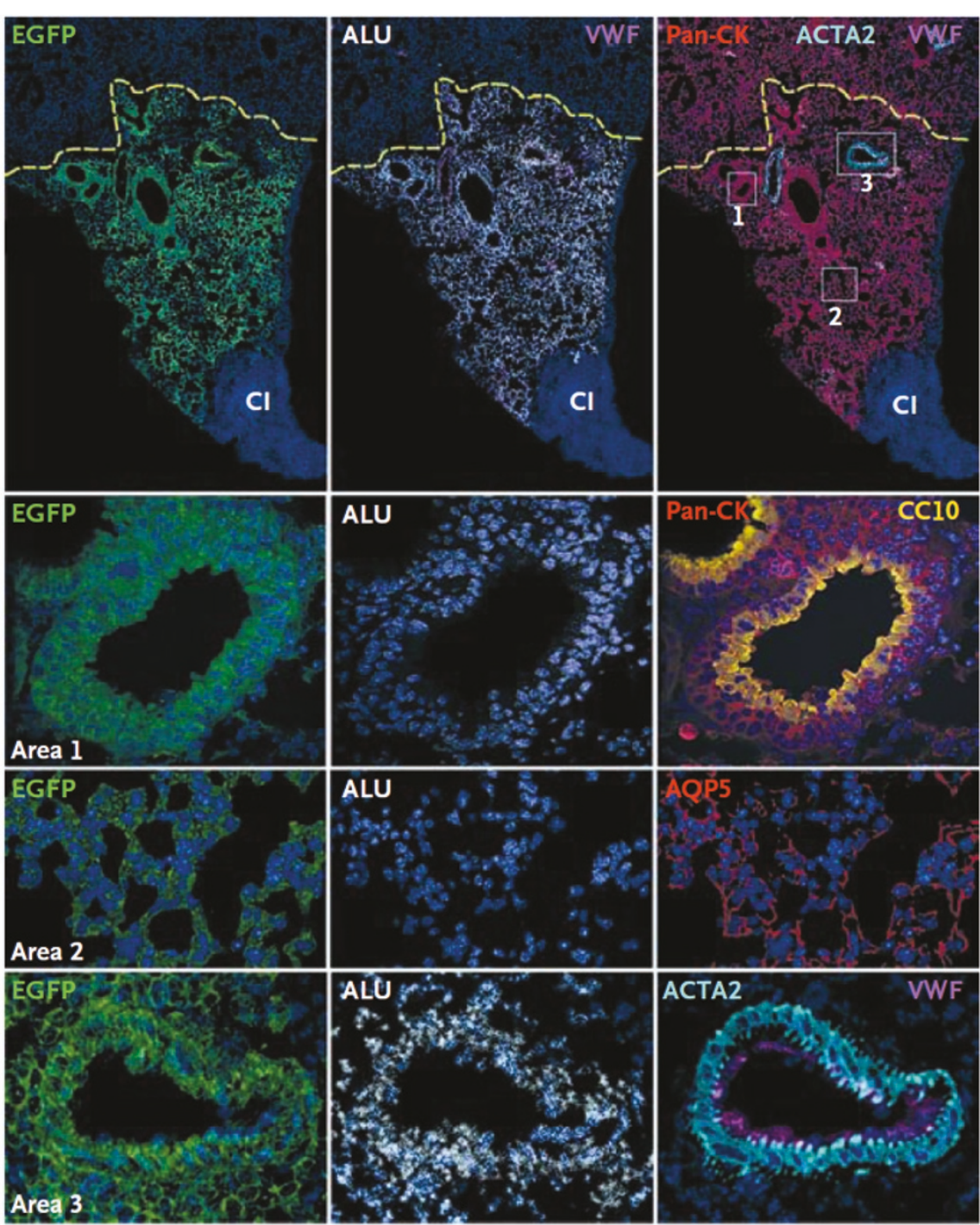

Figure 8. Human lung stem cells regenerate the injured mouse lung. Photomicrographs demonstrating engraftment of human lung c-kitpositive cells into the cryo-injured mouse lung. These cells, which express green fluorescent protein (EGFP), regenerated the injured area of lung tissue. The c-kit-positive cells differentiated into lung epithelial cells (area 1), and formed lung bronchioles as evidenced by staining for Clara cell 10-kDa secretory protein (CC-10), alveolar lung tissue (area 2) as evidenced by staining for aquaporin-5 (AQP5), and pulmonary arterioles (area 3) as evidenced by staining for von-Willebrand factor (VWF). Reproduced with permission from [99].

differentiation of iPSCs into ATII-like epithelial cells is a welcome development [95]. However, there is evidence to suggest that iPSCs are neither as robust nor as pleuripotent as ESCs [96]. Moreover, the current gene transduction techniques for generating pluripotent cells are impractical for producing a clinically reliable stem cell source, especially for an acute illness such as ALI [97].

\section{Endogenous lung stem cells}

The ideal cell type to use to regenerate the injured lung would be the lung's native stem cell population. The ability of the lung to regenerate following injury provides clear evidence for the existence of one or more native lung stem cell populations [98]. Until recently, however, this putative adult lung-derived stem cell population remained poorly characterised. While several different possible populations of anatomically and functionally distinct endogenous stem cell candidates have been identified, none of these cells meet the full criteria of what constitutes a stem cell. However, in a landmark study Kajstura and colleagues [99] have recently identified a population of c-kit-positive stem cells in the human lung located in the distal lung, the bronchioles and to a lesser extent the alveoli, demonstrating the ability to regenerate all components of an injured mouse lung (Figure 8). This study has generated controversy, 
particularly in regard to the fact that key experiments lacked appropriate controls, and the fact that, by focusing on human c-kit-positive lung cells, these studies provide only partial insights into the fates of these cells $[100,101]$. The novelty of these findings is underlined by the fact that multipotent stem cells that can give rise to both endodermal and mesodermal lineages have not previously been described in the lung, nor indeed in any organ. In other studies, Chapman and colleagues [102] identified a novel integrin $\alpha 6 \beta 4$-expressing alveolar epithelial cell in the mouse lung that can repair the lung following ALI. Hegab and colleagues [103] provide convincing evidence that submucosal gland duct cells constitute a stem/progenitor cell population. Taken together, these studies offer considerable promise for a therapeutic role for endogenous lung stem/progenitor cells in lung diseases such as ALI/ARDS.

\section{Barriers to clinical translation}

It is not known whether the regenerative capacity demonstrated by these c-kit-positive stem cells can be replicated in human lung, and indeed whether the tissue produced will function as normal lung. Likewise, the feasibility of harvesting endogenous stem cells from a critically ill ALI/ARDS patient is unclear. It is likely that the first clinical applications of lung stem cells will be in the field of tissue bioengineering for chronic conditions such as tracheal atresia

\section{Conclusion}

Stem cells constitute a promising therapeutic strategy for patients suffering from ALI/ARDS. MSCs appear closest to clinical translation, given the evidence that they may favourably modulate the immune response to reduce lung injury, while maintaining host immune-competence and also facilitating lung regeneration and repair. The demonstration that human MSCs exert benefit in the endotoxin-injured human lung is particularly persuasive. However, gaps remain in our knowledge regarding the mechanisms of action of MSCs, the optimal MSC administration and dosage regimens, and the safety of MSCs in critically ill patients. It is anticipated that these remaining knowledge deficits will be addressed in ongoing and future studies. Other stem cells, such as ESCs and iPCs, are at an earlier stage in the translational process, but offer the hope of directly replacing injured lung tissue. Ultimately, lung-derived stem cells may offer the greatest hope for lung diseases, given their role in replacing and repairing the native damaged lung tissues.

\section{Abbreviations}

ALI, acute lung injury; ARDS, acute respiratory distress syndrome; ATII, alveolar type II; EPC, endothelial progenitor cell; ESC, embryonic stem cell; IL, interleukin; iPSC, induced pluripotent stem cell; MSC, mesenchymal stem cell; TSG, tumour necrosis factor-a-induced protein.

\section{Competing interests}

The authors declare that they have no competing interests.

\section{Acknowledgements}

This work was supported by funding from the Health Research Board, Dublin, Ireland (grant number RP/2008/193), and the European Research Council, Brussels, Belgium, under the Framework 7 Programme (grant number ERC2007-StG 207777)

\section{Author details}

'Lung Biology Group, Regenerative Medicine Institute, National Centre for Biomedical Engineering Science, National University of Ireland, Galway. ${ }^{2}$ Department of Anaesthesia, Clinical Sciences Institute, National University of Ireland, Galway, Galway, Ireland. ${ }^{3}$ Anaesthesia, School of Medicine, Clinica Sciences Institute, National University of Ireland, Galway, Galway, Ireland.

Published: 16 March 2011

References

1. Rubenfeld GD, Herridge MS: Epidemiology and outcomes of acute lung injury. Chest 2007, 131:554-562.

2. Herridge MS, Cheung AM, Tansey CM, Matte-Martyn A, Diaz-Granados N, Al-Saidi F, Cooper AB, Guest CB, Mazer CD, Mehta S, Stewart TE, Barr A, Cook D, Slutsky AS: One-year outcomes in survivors of the acute respiratory distress syndrome. N Engl J Med 2003, 348:683-693.

3. England TN: Ventilation with lower tidal volumes as compared with traditional tidal volumes for acute lung injury and the acute respiratory distress syndrome. The Acute Respiratory Distress Syndrome Network. NEngl J Med 2000, 342:1301-1308.

4. Angus DC, Clermont G, Linde-Zwirble WT, Musthafa AA, Dremsizov TT, Lidicker J, Lave JR: Healthcare costs and long-term outcomes after acute respiratory distress syndrome: A phase III trial of inhaled nitric oxide. Crit Care Med 2006, 34:2883-2890.

5. Taylor RW, Zimmerman JL, Dellinger RP, Straube RC, Criner GJ, Davis K Jr, Kelly KM, Smith TC, Small RJ: Low-dose inhaled nitric oxide in patients with acute lung injury: a randomized controlled trial. JAMA 2004, 291:1603-1609.

6. Bernard G, Wheeler A, Naum C, Morris P, Nelson L, Schein R: A placebo controlled, randomised trail of IL-10 in acut lung injury (ALI). Chest 1999, 116 (4 Suppl 2):260S

7. Ortolani O, Conti A, De Gaudio AR, Masoni M, Novelli G: Protective effects of $\mathrm{N}$-acetylcysteine and rutin on the lipid peroxidation of the lung epithelium during the adult respiratory distress syndrome. Shock 2000, 13:14-18.

8. Domenighetti G, Suter PM, Schaller MD, Ritz R, Perret C: Treatment with $\mathrm{N}$-acetylcysteine during acute respiratory distress syndrome: a randomized, double-blind, placebo-controlled clinical study. J Crit Care 1997, 12:177-182.

9. Suter PM, Domenighetti G, Schaller MD, Laverriere MC, Ritz R, Perret C: $\mathrm{N}$-acetylcysteine enhances recovery from acute lung injury in man. A randomized, double-blind, placebo-controlled clinical study. Chest 1994, 105:190-194

10. Taut FJ, Rippin G, Schenk P, Findlay G, Wurst W, Hafner D, Lewis JF, Seeger W, Gunther A, Spragg RG: A Search for subgroups of patients with ARDS who may benefit from surfactant replacement therapy: a pooled analysis of five studies with recombinant surfactant protein-C surfactant (Venticute) Chest 2008, 134:724-732.

11. Thompson BT: Glucocorticoids and acute lung injury. Crit Care Med 2003, 31(4 Suppl):S253-257.

12. Bernard G, Wheeler A, Naum C, Morris P, Nelson L, Schein R: A placebo controlled, randomised trail of IL-10 in acute lung injury (ALI). Chest 1999, 116 (Suppl):260S.

13. Presneill JJ, Harris T, Stewart AG, Cade JF, Wilson JW: A randomized phase II trial of granulocyte-macrophage colony-stimulating factor therapy in severe sepsis with respiratory dysfunction. Am J Resp Crit Care Med 2002, 166:138-143.

14. Wiedemann HP, Wheeler AP, Bernard GR, Thompson BT, Hayden D, deBoisblanc B, Connors AF Jr, Hite RD, Harabin AL: Comparison of two fluidmanagement strategies in acute lung injury. N Engl J Med 2006, 354:2564-2575.

15. Abroug F, Ouanes-Besbes L, Elatrous S, Brochard L: The effect of prone positioning in acute respiratory distress syndrome or acute lung injury: 
a meta-analysis. Areas of uncertainty and recommendations for research Intensive Care Med 2008, 34:1002-1011.

16. Sud S, Friedrich JO, Taccone P, Polli F, Adhikari NK, Latini R, Pesenti A, Guerin C, Mancebo J, Curley MA, Fernandez R, Chan MC, Beuret P, Voggenreiter G, Sud $M$, Tognoni $G$, Gattinoni L: Prone ventilation reduces mortality in patients with acute respiratory failure and severe hypoxemia: systematic review and meta-analysis. Intensive Care Med 2010, 36:585-599.

17. Erickson SE, Martin GS, Davis JL, Matthay MA, Eisner MD: Recent trends in acute lung injury mortality: 1996-2005. Crit Care Med 2009, 37:1574-1579.

18. Weiss DJ, Kolls JK, Ortiz La, Panoskaltsis-Mortari A, Prockop DJ: Stem cells and cell therapies in lung biology and lung diseases. Proc Am Thorac Soc 2008, 5:637-667.

19. Sueblinvong V, Weiss DJ: Cell therapy approaches for lung diseases: current status. Curr Opin Pharmacol 2009, 9:268-273.

20. Ware LB, Matthay MA: The acute respiratory distress syndrome. N Engl J Med 2000, 342:1334-1349.

21. Bruno S, Grange C, Deregibus MC, Calogero RA, Saviozzi S, Collino F, Morando L, Busca A, Falda M, Bussolati B, Tetta C, Camussi G: Mesenchymal stem cellderived microvesicles protect against acute tubular injury. J Am SoC Nephrol 2009, 20:1053-1067.

22. Gatti S, Bruno S, Deregibus MC, Sordi A, Cantaluppi V, Tetta C, Camussi G: Microvesicles derived from human adult mesenchymal stem cells protect against ischaemia-reperfusion-induced acute and chronic kidney injury. Nephrol Dial Transplant 2011, 26:1474-1483.

23. Kanazawa H, Fujimoto Y, Teratani T, I wasaki J, Kasahara N, Negishi K, Tsuruyama T, Uemoto S, Kobayashi E: Bone marrow-derived mesenchymal stem cells ameliorate hepatic ischemia reperfusion injury in a rat model. PLoS One 2011, 6:e19195.

24. Kharaziha P, Hellstrom PM, Noorinayer B, Farzaneh F, Aghajani K, Jafari F, Telkabadi M, Atashi A, Honardoost M, Zali MR, Soleimani M: Improvement of liver function in liver cirrhosis patients after autologous mesenchymal stem cell injection: a phase I-II clinical trial. Eur J Gastroenterol Hepatol 2009, 21:1199-1205.

25. Hare JM, Chaparro SV: Cardiac regeneration and stem cell therapy. Curr Opin Organ Transplant 2008, 13:536-542.

26. Eisner MD, Thompson T, Hudson LD, Luce JM, Hayden D, Schoenfeld D, Matthay MA: Efficacy of low tidal volume ventilation in patients with different clinical risk factors for acute lung injury and the acute respiratory distress syndrome. Am J Respir Crit Care Med 2001, 164:231-236.

27. Doyle RL, Szaflarski N, Modin GW, Wiener-Kronish JP, Matthay MA: Identification of patients with acute lung injury. Predictors of mortality. Am J Respir Crit Care Med 1995, 152:1818-1824.

28. Mei SHJ, Haitsma JJ, Dos Santos CC, Deng Y, Lai PFH, Slutsky AS, Liles WC, Stewart DJ: Mesenchymal stem cells reduce inflammation while enhancing bacterial clearance and improving survival in sepsis. Am J Respir Crit Care Med 2010, 182:1047-1057.

29. Krasnodembskaya A, Song Y, Fang X, Gupta N, Serikov V, Lee J-W, Matthay Ma: Antibacterial effect of human mesenchymal stem cells is mediated in part from secretion of the antimicrobial peptide LL-37. Stem cells 2010, 28:2229-2238

30. Chapel A, Bertho JM, Bensidhoum M, Fouillard L, Young RG, Frick J, Demarquay C, Cuvelier Fdr, Mathieu E, Trompier Fo, Dudoignon N, Germain C, Mazurier C, Aigueperse J, Borneman J, Gorin NC, Gourmelon P, Thierry D: Mesenchymal stem cells home to injured tissues when co-infused with hematopoietic cells to treat a radiation-induced multi-organ failure syndrome. J Gene Med 2003, 5:1028-1038.

31. Mei SHJ, McCarter SD, Deng Y, Parker CH, Liles WC, Stewart DJ: Prevention of LPS-induced acute lung injury in mice by mesenchymal stem cells overexpressing angiopoietin 1. PLoS Med 2007, 4:e269-e269.

32. MacLoughlin RJ, Higgins BD, Laffey JG, O'Brien T: Optimized aerosol delivery to a mechanically ventilated rodent. J Aerosol Med Pulm Drug Deliv 2009, 22:323-332.

33. Lee JW, Fang X, Gupta N, Serikov V, Matthay Ma: Allogeneic human mesenchymal stem cells for treatment of $E$. coli endotoxin-induced acute lung injury in the ex vivo perfused human lung. Proc Natl Acad Sci U S A 2009, 106:16357-16362.

34. Wang D, Haviland DL, Burns AR, Zsigmond E, Wetsel RA: A pure population of lung alveolar epithelial type II cells derived from human embryonic stem cells. Proc Natl Acad Sci U S A 2007, 104:4449-4454

35. Pittenger MF, Mackay AM, Beck SC, Jaiswal RK, Douglas R, Mosca JD, Moorman MA, Simonetti DW, Craig S, Marshak DR: Multilineage potential of adult human mesenchymal stem cells. Science 1999, 284:143-147.

36. Eguchi G, Kodama R: Transdifferentiation. Curr Opin Cell Biol 1993, 5:1023-1028.

37. Krause DS, Theise ND, Collector MI, Henegariu O, Hwang S, Gardner R, Neutzel $\mathrm{S}$, Sharkis SJ: Multi-organ, multi-lineage engraftment by a single bone marrow-derived stem cell. Cell 2001, 105:369-377.

38. Kotton DN, Ma BY, Cardoso WV, Sanderson EA, Summer RS, Williams MC, Fine A: Bone marrow-derived cells as progenitors of lung alveolar epithelium. Development 2001, 128:5181-5188.

39. Suratt BT, Cool CD, Serls AE, Chen L, Varella-Garcia M, Shpall EJ, Brown KK, Worthen GS: Human pulmonary chimerism after hematopoietic stem cell transplantation. Am J Respir Crit Care Med 2003, 168:318-322.

40. Gupta N, Su X, Popov B, Lee JW, Serikov V, Matthay MA: Intrapulmonary delivery of bone marrow-derived mesenchymal stem cells improves survival and attenuates endotoxin-induced acute lung injury in mice. J Immunol 2007, 179:1855-1863.

41. Ortiz La, Dutreil M, Fattman C, Pandey AC, Torres G, Go K, Phinney DG: Interleukin 1 receptor antagonist mediates the antiinflammatory and antifibrotic effect of mesenchymal stem cells during lung injury. Proc Nat Acad Sci U S A 2007, 104:11002-11007.

42. Neuss S, Becher E, Woltje M, Tietze L, Jahnen-Dechent W: Functional expression of HGF and HGF receptor/c-met in adult human mesenchymal stem cells suggests a role in cell mobilization, tissue repair, and wound healing. Stem Cells 2004, 22:405-414

43. Fang $X$, Neyrinck AP, Matthay MA, Lee JW: Allogeneic human mesenchymal stem cells restore epithelial protein permeability in cultured human alveolar type II cells by secretion of angiopoietin-1. J Biol Chem 2010 285:26211-26222.

44. Németh Kn, Leelahavanichkul A, Yuen PST, Mayer Bz, Parmelee A, Doi K, Robey PG, Leelahavanichkul K, Koller BH, Brown JM, Hu X, Jelinek I, Star Ra, Mezey E: Bone marrow stromal cells attenuate sepsis via prostaglandin $E(2)$-dependent reprogramming of host macrophages to increase their interleukin-10 production. Nat Med 2009, 15:42-49.

45. Augello A, Tasso R, Negrini SM, Amateis A, Indiveri F, Cancedda R, Pennesi G: Bone marrow mesenchymal progenitor cells inhibit lymphocyte proliferation by activation of the programmed death 1 pathway. Eur $\int$ Immunol 2005, 35:1482-1490.

46. Danchuk S, Ylostalo JH, Hossain F, Sorge R, Ramsey A, Bonvillain RW, Lasky JA, Bunnell BA, Welsh DA, Prockop DJ, Sullivan DE: Human multipotent stromal cells attenuate lipopolysaccharide-induced acute lung injury in mice via secretion of tumor necrosis factor-alpha-induced protein 6 . Stem Cell Res Ther 2011, 2:27.

47. Matthay Ma, Thompson BT, Read EJ, McKenna DH, Liu KD, Calfee CS, Lee JW: Therapeutic potential of mesenchymal stem cells for severe acute lung injury. Chest 2010, 138:965-972.

48. Friedenstein AJ, Gorskaja JF, Kulagina NN: Fibroblast precursors in normal and irradiated mouse hematopoietic organs. Exp Hematol 1976, 4:267-274.

49. Moodley Y, Manuelpillai U, Weiss DJ: Cellular therapies for lung disease: a distant horizon. Respirology 2001, 16:223-237.

50. Ortiz La, Gambelli F, McBride C, Gaupp D, Baddoo M, Kaminski N, Phinney DG Mesenchymal stem cell engraftment in lung is enhanced in response to bleomycin exposure and ameliorates its fibrotic effects. Proc Natl Acad Sci USA 2003, 100:8407-8411.

51. van Haaften T, Byrne R, Bonnet S, Rochefort GY, Akabutu J, Bouchentouf M, Rey-Parra GJ, Galipeau J, Haromy A, Eaton F, Chen M, Hashimoto K, Abley D, Korbutt G, Archer SL, Thebaud B: Airway delivery of mesenchymal stem cells prevents arrested alveolar growth in neonatal lung injury in rats. Am J Respir Crit Care Med 2009, 180:1131-1142.

52. Aslam M, Baveja R, Liang OD, Fernandez-Gonzalez A, Lee C, Mitsialis SA, Kourembanas $\mathrm{S}$ : Bone marrow stromal cells attenuate lung injury in a murine model of neonatal chronic lung disease. Am J Respir Crit Care Med 2009, 180:1122-1130

53. Curley GF, Hayes M, Higgins B, Shaw G, Ryan A, Barry F, O'Brien T, O'Toole D, Laffey JG: Mesenchymal stem cells enhance recovery and repair following ventilation induced lung injury in the rat. Thorax 2011 [Epub ahead of print].

54. Curley GF, Contreras M, Higgins B, O'Kane C, McAuley DF, O'Toole D, Laffey JG: Evolution of the inflammatory and fibroproliferative responses during resolution and repair following ventilator-induced lung injury in the rat. Anesthesiology 2011, 115:1022-1032.

55. Xu J, Woods CR, Mora AL, Joodi R, Brigham KL, Iyer S, Rojas M: Prevention of 
endotoxin-induced systemic response by bone marrow-derived mesenchymal stem cells in mice. Am J Physiol Lung Cell Mol Physio/ 2007, 293:L131-141.

56. Mao M, Wang S-N, Lv X-J, Wang Y, Xu J-C: Intravenous delivery of bone marrow-derived endothelial progenitor cells improves survival and attenuates lipopolysaccharide-induced lung injury in rats. Shock 2010, 34:196-204.

57. Miyahara Y, Nagaya N, Kataoka M, Yanagawa B, Tanaka K, Hao H, Ishino K, Ishida H, Shimizu T, Kangawa K, Sano S, Okano T, Kitamura S, Mori H: Monolayered mesenchymal stem cells repair scarred myocardium after myocardial infarction. Nat Med 2006, 12:459-465.

58. Lee RH, Seo MJ, Reger RL, Spees JL, Pulin AA, Olson SD, Prockop DJ: Multipotent stromal cells from human marrow home to and promote repair of pancreatic islets and renal glomeruli in diabetic NOD/scid mice. Proc Natl Acad Sci U S A 2006, 103:17438-17443.

59. Parekkadan B, van Poll D, Suganuma K, Carter EA, Berthiaume F, Tilles AW, Yarmush ML: Mesenchymal stem cell-derived molecules reverse fulminant hepatic failure. PLoS One 2007, 2:e941.

60. Togel F, Hu Z, Weiss K, Isaac J, Lange C, Westenfelder C: Administered mesenchymal stem cells protect against ischemic acute renal failure through differentiation-independent mechanisms. Am J Physiol Renal Physiol 2005, 289:F31-42.

61. Lee JW, Fang X, Gupta N, Serikov V, Matthay MA: Allogeneic human mesenchymal stem cells for treatment of $E$. coli endotoxin-induced acute lung injury in the ex vivo perfused human lung. Proc Natl Acad Sci U S A 2009, 106:16357-16362.

62. Kursova LV, Konoplyannikov AG, Pasov W, Ivanova IN, Poluektova MV, Konoplyannikova OA: Possibilities for the use of autologous mesenchymal stem cells in the therapy of radiation-induced lung injuries. Bull Exp Biol Med 2009, 147:542-546.

63. Hare JM, Traverse JH, Henry TD, Dib N, Strumpf RK, Schulman SP, Gerstenblith G, DeMaria AN, Denktas AE, Gammon RS, Hermiller JB Jr, Reisman MA, Schaer GL, Sherman W: A randomized, double-blind, placebo-controlled, doseescalation study of intravenous adult human mesenchymal stem cells (prochymal) after acute myocardial infarction. J Am Coll Cardio/ 2009, 54:2277-2286

64. Falanga V, Iwamoto S, Chartier M, Yufit T, Butmarc J, Kouttab N, Shrayer D, Carson P: Autologous bone marrow-derived cultured mesenchymal stem cells delivered in a fibrin spray accelerate healing in murine and human cutaneous wounds. Tissue Eng 2007, 13:1299-1312

65. McFarlin K, Gao X, Liu YB, Dulchavsky DS, Kwon D, Arbab AS, Bansal M, Li Y Chopp M, Dulchavsky SA, Gautam SC: Bone marrow-derived mesenchymal stromal cells accelerate wound healing in the rat. Wound Repair Regen 2006, 14:471-478.

66. Wu Y, Chen L, Scott PG, Tredget EE: Mesenchymal stem cells enhance wound healing through differentiation and angiogenesis. Stem cells 2007 25:2648-2659.

67. Griffin MD, Ritter T, Mahon BP: Immunological aspects of allogeneic mesenchymal stem cell therapies. Hum Gene Ther 2010, 21:1641-1655.

68. Nemeth K, Keane-Myers A, Brown JM, Metcalfe DD, Gorham JD, Bundoc VG, Hodges MG, Jelinek I, Madala S, Karpati S, Mezey E: Bone marrow stromal cells use TGF-beta to suppress allergic responses in a mouse model of ragweed-induced asthma. Proc Natl Acad Sci U S A 2010, 107:5652-5657.

69. Meisel R, Brockers S, Heseler K, Degistirici O, Bulle H, Woite C, Stuhlsatz S, Schwippert W, Jager M, Sorg R, Henschler R, Seissler J, Dilloo D, Daubener W: Human but not murine multipotent mesenchymal stromal cells exhibit broad-spectrum antimicrobial effector function mediated by indoleamine 2,3-dioxygenase. Leukemia 2011, 25:648-654

70. Smith JR, Pochampally R, Perry A, Hsu SC, Prockop DJ: Isolation of a highly clonogenic and multipotential subfraction of adult stem cells from bone marrow stroma. Stem cells 2004, 22:823-831

71. Dominici M, Le Blanc K, Mueller I, Slaper-Cortenbach I, Marini F, Krause D, Deans R, Keating A, Prockop D, Horwitz E: Minimal criteria for defining multipotent mesenchymal stromal cells. The International Society for Cellular Therapy position statement. Cytotherapy 2006, 8:315-317.

72. Ahrlund-Richter L, De Luca M, Marshak DR, Munsie M, Veiga A, Rao M: Isolation and production of cells suitable for human therapy: challenges ahead. Cell Stem Cell 2009, 4:20-26.

73. Nauta AJ, Fibbe WE: Immunomodulatory properties of mesenchymal stromal cells. Blood 2007, 110:3499-3506.

74. Nauta AJ, Westerhuis G, Kruisselbrink AB, Lurvink EGa, Willemze R, Fibbe WE:
Donor-derived mesenchymal stem cells are immunogenic in an allogeneic host and stimulate donor graft rejection in a nonmyeloablative setting. Blood 2006, 108:2114-2120.

75. Rehman J, Li J, Orschell CM, March KL: Peripheral blood "endothelial progenitor cells" are derived from monocyte/macrophages and secrete angiogenic growth factors. Circulation 2003, 107:1164-1169.

76. Lam C-F, Liu Y-C, Hsu J-K, Yeh P-A, Su T-Y, Huang C-C, Lin M-W, Wu P-C, Chang $P-J$, Tsai Y-C: Autologous transplantation of endothelial progenitor cells attenuates acute lung injury in rabbits. Anesthesiology 2008, 108:392-401.

77. Burnham EL, Taylor WR, Quyyumi Aa, Rojas M, Brigham KL, Moss M: Increased circulating endothelial progenitor cells are associated with survival in acute lung injury. Am J Respir Crit Care Med 2005, 172:854-860.

78. Yamada M, Kubo H, Kobayashi S, Ishizawa K, Numasaki M, Ueda S, Suzuki T, Sasaki H: Bone marrow-derived progenitor cells are important for lung repair after lipopolysaccharide-induced lung injury. J Immuno/ 2004 172:1266-1272.

79. Zhu JH, Wang XX, Zhang FR, Shang YP, Tao QM, Zhu JH, Chen JZ: Safety and efficacy of autologous endothelial progenitor cells transplantation in children with idiopathic pulmonary arterial hypertension: open-label pilot study. Pediatr Transplant 2008, 12:650-655.

80. Wang X-X, Zhang F-R, Shang Y-P, Zhu J-H, Xie X-D, Tao Q-M, Zhu J-H, Chen J-Z: Transplantation of autologous endothelial progenitor cells may be beneficial in patients with idiopathic pulmonary arterial hypertension: a pilot randomized controlled trial. J Am Coll Cardio/ 2007, 49:1566-1571.

81. Hemmen K, Reinl T, Buttler K, Behler F, Dieken H, Jansch L, Wilting J, Weich HA: High-resolution mass spectrometric analysis of the secretome from mouse lung endothelial progenitor cells. Angiogenesis 2011, 14:163-172.

82. Hristov M, Erl W, Weber PC: Endothelial progenitor cells: mobilization, differentiation, and homing. Arterioscler Thromb Vasc Bio/ 2003 23:1185-1189.

83. Roszell B, Mondrinos MJ, Seaton A, Simons DM, Koutzaki SH, Fong G-H, Lelkes $\mathrm{PI}$, Finck CM: Efficient derivation of alveolar type II cells from embryonic stem cells for in vivo application. Tiss Eng Part A 2009, 15:3351-3365.

84. Wang D, Haviland DL, Burns AR, Zsigmond E, Wetsel Ra: A pure population of lung alveolar epithelial type II cells derived from human embryonic stem cells. Proc Natl Acad Sci U S A 2007, 104:4449-4454

85. Roszell B, Mondrinos MJ, Seaton A, Simons DM, Koutzaki SH, Fong G-H, Lelkes $\mathrm{PI}$, Finck CM: Efficient derivation of alveolar type II cells from embryonic stem cells for in vivo application. Tiss Eng Part A 2009, 15:3351-3365.

86. Van Vranken BE, Romanska HM, Polak JM, Rippon HJ, Shannon JM, Bishop AE: Coculture of embryonic stem cells with pulmonary mesenchyme: a microenvironment that promotes differentiation of pulmonary epithelium. Tiss Eng 2005, 11:1177-1187.

87. Rippon HJ, Lane S, Qin M, Ismail NS, Wilson MR, Takata M, Bishop AE: Embryonic stem cells as a source of pulmonary epithelium in vitro and in vivo. Proc Am Thorac Soc 2008, 5:717-722.

88. Wang D, Morales JE, Calame DG, Alcorn JL, Wetsel RA: Transplantation of human embryonic stem cell-derived alveolar epithelial type II cells abrogates acute lung injury in mice. Mol Ther 2010, 18:625-634.

89. Toya SP, Li F, Bonini MG, Gomez I, Mao M, Bachmaier KW, Malik AB: Interaction of a specific population of human embryonic stem cell-derived progenitor cells with CD11b+cells ameliorates sepsis-induced lung inflammatory injury. Am J Path 2011, 178:313-324.

90. Blum B, Benvenisty N: The tumorigenicity of human embryonic stem cells. Adv Cancer Res 2008, 100:133-158.

91. English K, Wood KJ: Immunogenicity of embryonic stem cell-derived progenitors after transplantation. Curr Opin Organ Transplant 2010 [Epub ahead of print]

92. Magatti M, De Munari S, Vertua E, Gibelli L, Wengler GS, Parolini O: Human amnion mesenchyme harbors cells with allogeneic T-cell suppression and stimulation capabilities. Stem cells 2008, 26:182-192

93. Dua HS, Gomes JAP, King AJ, Maharajan VS: The amniotic membrane in ophthalmology. Surv Ophthalmol 2004, 49:51-77.

94. Moodley Y, Atienza D, Manuelpillai U, Samuel CS, Tchongue J, llancheran S, Boyd R, Trounson A: Human umbilical cord mesenchymal stem cells reduce fibrosis of bleomycin-induced lung injury. Am J Pathol 2009, 175:303-313.

95. Alipio ZA, Jones N, Liao W, Yang J, Kulkarni S, Sree Kumar K, Hauer-Jensen M, Ward DC, Ma Y, Fink LM: Epithelial to mesenchymal transition (EMT) induced by bleomycin or TFG(b1)/EGF in murine induced pluripotent stem cell-derived alveolar Type II-like cells. Differentiation 2011, 82:89-98

96. Osafune K, Caron L, Borowiak M, Martinez RJ, Fitz-Gerald CS, Sato Y, Cowan 
Ca, Chien KR, Melton DA: Marked differences in differentiation propensity among human embryonic stem cell lines. Nat Biotechno/ 2008, 26:313-315.

97. Nishikawa S-i, Goldstein RA, Nierras CR: The promise of human induced pluripotent stem cells for research and therapy. Nat Rev Mol Cell Biol 2008, 9:725-729.

98. Giangreco A, Arwert EN, Rosewell IR, Snyder J, Watt FM, Stripp BR: Stem cells are dispensable for lung homeostasis but restore airways after injury. Proc Natl Acad Sci U S A 2009, 106:9286-9291.

99. Kajstura J, Rota M, R HS, Hosoda T, Sanada F, Zheng H, Ogorek B, Rondonclavo C, Ferreira-martins Jo, Matsuda A, Arranto C, Goichberg P, Giordano G, Haley KJ, Bardelli S, Rayatzadeh H, Liu X, Quaini F, Liao R, Leri A, Perrella MA, Loscalzo J, Anversa P: Evidence for human lung stem cells. N Engl J Med 2011, 364:1795-1806.

100. Chapman HA: Toward lung regeneration. N Engl J Med 2011, 364:1867-1868.

101. Hayes M, Curley GF, Laffey JG: Lung stem cells - from an evolving understanding to a paradigm shift? Stem Cell Res Ther 2011, 2:41.

102. Chapman HA, Li X, Alexander JP, Brumwell A, Lorizio W, Tan K, Sonnenberg A, Wei Y, Vu TH: Integrin alpha6beta4 identifies an adult distal lung epithelial population with regenerative potential in mice. J Clin Invest 2011, 121:2855-2862.
103. Hegab AE, Ha VL, Gilbert JL, Zhang KX, Malkoski SP, Chon AT, Darmawan DO, Bisht B, Ooi AT, Pellegrini M, Nickerson DW, Gomperts BN: Novel stem/ progenitor cell population from murine tracheal submucosal gland ducts with multipotent regenerative potential. Stem Cells 2011, 29:1283-1293.

104. Griffiths MJ, Bonnet D, Janes SM: Stem cells of the alveolar epithelium. Lancet 2005, 366:249-260.

105. Rawlins EL, Hogan BL: Epithelial stem cells of the lung: privileged few or opportunities for many? Development 2006, 133:2455-2465.

106. Chun YS, Chaudhari $P$, Jang YY: Applications of patient-specific induced pluripotent stem cells; focused on disease modeling, drug screening and therapeutic potentials for liver disease. Int J Biol Sci 2010, 6:796-805.

doi:10.1186/cc10570

Cite this article as: Hayes M, et al.: Clinical review: Stem cell therapies for acute lung injury/acute respiratory distress syndrome - hope or hype?

Critical Care 2012, 16:205 